\title{
Intellectual property policy of universities: specific regulation
}

\section{Política de propriedade intelectual das universidades: regulamento específico}

\section{Política de propiedad intelectual de las universidades: regulación específica}

\author{
Alexander Evgenievich Suglobov ${ }^{1}$ (D), Katerina Sergeevna Orlova ${ }^{2}$ (D), \\ Alexander Konstantinovich Kalliopin ${ }^{3}$ (D) , Petr Katys ${ }^{4}$ (D), \\ Aleksey Valeryevich Novikov ${ }^{5,6}$
}

\footnotetext{
${ }^{1}$ Financial University under the Government of the Russian Federation, Moscow, Russia.

2 K.G. Razumovsky Moscow State University of Technologies and Management (First Cossack University), Moscow, Russia.

${ }^{3}$ Moscow Aviation Institute, Moscow, Russia.

${ }^{4}$ Federal Government Institution Scientific and Production Association Special Equipment and Telecoms of the Ministry of Internal Affairs of the Russian Federation, Moscow, Russia.

5 Research Institute of the Federal Penitentiary Service of Russia, Moscow, Russia; Astrakhan State University, Astrakhan, Russia.
}

\section{Corresponding author:}

Alexander Evgenievich Suglobov

Email: a_suglobov@mail.ru

How to cite: Suglobov, A. E., Orlova, K. S., Zharov, A. N., Katys, P., \& Novikov, A. V. (2021). Intellectual property policy of universities: specific regulation. Revista Tempos e Espaços em Educação, 14(33), e16155.

http://dx.doi.org/10.20952/revtee.v14i33.16155

\begin{abstract}
This article considers the formation and implementation of a policy in relation to intellectual property in the activities of a higher education institution. Nowadays the creation, protection and commercialization of intellectual property objects are especially relevant for universities. The comprehensive solution of such issues stipulates the need for the development, adoption and implementation of university policies in relation to intellectual property objects as local regulatory acts. This study aims at analyzing intellectual property management policies in higher education institutions. The authors of the article have highlighted the key aspects of an intellectual property object as an object of management. To prove the relationship between intellectual property law and regulation that allows a university to own and freely dispose of its intangible assets, the article dwells on the best practices of European and US universities in terms of issuing local legal acts. The authors have concluded that it is inexpedient to copy the US university policy in Russia due to different approaches to intellectual property. They have developed the concept of strategic
\end{abstract}


management of intellectual property based on the national legislation on the protection and disposal of intellectual property and local regulations of higher education institutions.

Keywords: University policy. Intellectual deliverable. Intellectual property. Management. Commercialization.

\section{RESUMO}

Este artigo considera a formação e implementação de uma política em relação à propriedade intelectual nas atividades de uma instituição de ensino superior. Hoje em dia, a criação, proteção e comercialização de objetos de propriedade intelectual são especialmente relevantes para as universidades. A solução integral de tais questões prevê a necessidade de desenvolvimento, adoção e implementação de políticas universitárias em relação aos objetos de propriedade intelectual como atos regulatórios locais. Este estudo tem como objetivo analisar as políticas de gestão da propriedade intelectual em instituições de ensino superior. Os autores do artigo destacaram os principais aspectos de um objeto de propriedade intelectual como objeto de gestão. Para provar a relação entre a lei de propriedade intelectual e a regulamentação que permite a uma universidade possuir e dispor livremente de seus ativos intangíveis, o artigo trata das melhores práticas das universidades europeias e americanas em termos de emissão de atos jurídicos locais. Os autores concluíram que é impróprio copiar a política universitária dos EUA na Rússia devido às diferentes abordagens à propriedade intelectual. Eles desenvolveram o conceito de gestão estratégica da propriedade intelectual com base na legislação nacional sobre a proteção e eliminação da propriedade intelectual e nas regulamentações locais das instituições de ensino superior.

Palavras-chave: Política da universidade. Entrega intelectual. Propriedade intelectual. Gestão. Comercialização.

\section{RESUMEN}

Este artículo considera la formación e implementación de una política en relación a la propiedad intelectual en las actividades de una institución de educación superior. Hoy en día la creación, protección y comercialización de objetos de propiedad intelectual son especialmente relevantes para las universidades. La solución integral de tales problemas estipula la necesidad de desarrollar, adoptar e implementar políticas universitarias en relación con los objetos de propiedad intelectual como actos regulatorios locales. Este estudio tiene como objetivo analizar las políticas de gestión de la propiedad intelectual en las instituciones de educación superior. Los autores del artículo han destacado los aspectos clave de un objeto de propiedad intelectual como objeto de gestión. Para probar la relación entre la ley de propiedad intelectual y la regulación que permite a una universidad poseer y disponer libremente de sus activos intangibles, el artículo se detiene en las mejores prácticas de las universidades europeas y estadounidenses en términos de emisión de actos legales locales. Los autores han llegado a la conclusión de que no es conveniente copiar la política universitaria estadounidense en Rusia debido a los diferentes enfoques de la propiedad intelectual. Han desarrollado el concepto de gestión estratégica de la propiedad intelectual basado en la legislación nacional sobre la protección y disposición de la propiedad intelectual y las regulaciones locales de las instituciones de educación superior.

Palabras clave: Política universitaria. Entregable intelectual. Propiedad intelectual. Gestión. Comercialización.

\section{INTRODUCTION}

Currently, typical features of economic growth are the intellectualization of the main factors of production and innovative development (Abdulkadyrov et al., 2021; Glinkina et al., 2020). The share of intellectual property rights in Russian and international civil relations is constantly growing. The world trade in intellectual property rights expands much faster than industrial production. By 
the beginning of the $21^{\text {st }}$ century, the total volume of world trade in the industrial property (patented and licensed inventions, industrial designs, know-how, R\&D results, software, etc.) had reached more than one hundred billion dollars. Copyright objects generate about 7\% of GDP (Ivanov et al., 2012). International experience testifies that the innovative development management of any organization should act adequately or proactively, responding to the possible changes associated with the emergence of innovative technologies and new types of services offered by the market. In this regard, the priority management system (as the most flexible) is a strategic management system. Such a management model will ensure the efficient use of the organization's intellectual capital, reduce the cost of producing goods and services, and create brand new products that are highly competitive in both national and foreign markets. The intensity of innovations and the efficiency of resources used for research and development largely depend on the legal protection of rights to intellectual deliverables (Zamiralova et al., 2020; Ermilov et al., 2020).

In recent years, a trend in the development of universities has been the search for ways to increase their competitiveness, and transform them into educational, scientific and innovative institutions (Shegelman, 2010). To become more competitive, universities should take on some functions of the sectoral science destroyed during the Perestroika, provided that a significant part of intellectual property was formed in the pre-Perestroika period. Assuming some functions of sectoral science (which is impossible without close interaction with industry and major sites for experimental production in most educational institutions), universities should also generate intellectual property objects, protect and commercialize them.

The effective management of intellectual property and other intellectual deliverables (Klimakina et al., 2020) to involve them in civil relations is one of the conditions for ensuring the successful development of universities.

The world's leading universities and research institutes that have achieved significant success in the commercialization of their scientific and technical activities develop their own policy in the field of intellectual property as an integral document. It reflects all the organizational and legal issues related to the creation, legal protection and use of intellectual property objects. At the same time, some scholars (Vasileva, 2018; Ryzhov, 2018) believe that, unlike the world's leading universities, the Russian universities lack a balanced policy in the field of intellectual property, which limits their possibilities of using intellectual property as a strategic resource.

The above-mentioned circumstances cause a certain interest in the development of various approaches to the management of intellectual property in a modern university and its approval in the form of a special document (local regulatory act). Attempts to present general principles of developing this policy were made by N.O. Yanykina (2011), N.G. Ryzhov (2018), A.Yu. Kalinin and Yu.V. Nechipurenko (2019) who studied the international experience of forming and implementing such a policy. These scientific works contribute to the development of university policies in relation to intellectual property. However, all the factors improving the current state of affairs have not been determined in the available studies, thus the research topic is still relevant. The study aims at analyzing the issues of forming an effective university policy for intellectual property management to develop the best approach. The research hypothesis is that an effective policy for managing the intellectual property of a university should be represented as a set of local regulations, organizational and legal mechanisms governing all the intellectual property objects that are subject to regulation.

\section{METHODS}

To conduct this research, we used a set of methods, including the dialectical method of cognizing reality. In addition, we applied the statistical and comparative-legal methods, the methods of system analysis, legal modeling and deduction. The theoretical basis of this article is provisions for the creation, management and protection of intellectual deliverables developed by 
scholars in the previous years. The informational basis is legal acts regulating the turnover of intellectual property objects, local regulatory acts that formalize the policy of universities on the management of intellectual property, and statistical data.

\section{RESULTS}

As a rule, research institutes in general and higher education institutions as integrated research and educational complexes in particular have exclusive rights to intellectual deliverables that are not much demanded by the business sector. The course towards the priority technological modernization of the Russian economy makes scientific and educational components of the national innovative system train personnel with new competences and form a powerful source of innovative ideas, technologies and projects. Such changes in goal setting also alter the methods of managing it as a business enterprise and drop the current models of non-economic behavior in favor of modern management concepts. Accordingly, it is necessary to form new strategic management of scientificeducational functioning and development in a dynamic competitive environment. First of all, this paradigm includes the development and implementation of new principles, methods and mechanisms for managing intellectual property (Yanykina, 2011).

Being a form of research activities, intellectual activity is part of the scientific and educational complex. The latter can be a separate institution of higher education, an association of universities, research and educational centers, resource sharing centers elaborating a specific direction of science and technology at the level of a region or country. Scientific and technical activities are understood as activities aimed at obtaining and applying new knowledge to solve technological, engineering, economic, social, humanitarian and other issues, as well as ensuring the functioning of science, technology and production as a unified system. At the same time, the result of the scientific and technical activity is the knowledge gained, recorded on an information carrier or a product containing this knowledge (Vinokurov, 2005).

Scientific literature more often uses the concept of intellectual deliverables. It embraces ways of solving technical and technological issues, technical innovations, knowledge, skills, methods of manufacturing products, software solutions and other results of mental work (Vinokurov, 2005). The group of intellectual deliverables can be also expanded with such intangible resources as means of identification of manufacturers and their products, which allows distinguishing between the products and services produced by different manufacturers.

In relation to the scientific and technical activities of universities, their results are regarded as intellectual deliverables.

The intellectual deliverables created by some university become its property, i.e. intellectual property. The "intellectual property" term means the possibility of using intellectual deliverables as intellectual property objects at one's own discretion and in one's own interests by taking any action in relation to these results that do not contradict the existing legislation and do not violate the rights and interests of other business entities.

Intellectual property rights are exclusive, i.e. the monopoly rights of an owner to use their intellectual property that prohibit its use by other persons and entities without the permission of the legal owner. Such conditions provide the owner of an intellectual property object with economic advantages over their competitors (Liotard, 1999). They intensify research and development activities, the legal protection and use of intellectual deliverables.

The features of intellectual property are as follows. Intellectual property should be viewed as an economic and legal category, applying mainly economic and legal management methods. While participating in economic relations as intellectual property objects, intellectual deliverables retain specific features associated with their role in the production process and acquire new ones due to the functioning of intellectual property. The system of the intellectual property comprises elements of this institute and economic relations. In this regard, any form of implementation of 
intellectual property relations should be analyzed comprehensively, i.e. from the viewpoint of both their economic content and institutional form. Moreover, this form and content should be considered in their close interaction and interdependence (Volkova, 2001).

Not all the products of intellectual labor are recognized as intellectual property objects. However, G. Yarygina (2011) claimed that the management of intellectual deliverables was impossible without the ownership of such results. To ensure the effective use of intellectual deliverables as tools of commercial activity, it is necessary to develop a specific policy of some organization.

In relation to universities, the need to form an intellectual property management policy is conditioned by the commercialization of higher education institutions, the growing number and share of private universities, the privatization of public institutions of higher education and the active introduction of corporate administration into the activities of universities (Bostock, 1999). The commercialization of intellectual property includes the introduction of intellectual deliverables into economic relations. This process is carried out, firstly, by transferring intellectual property rights among parties to the intellectual property market fully or partially, and secondly, by creating and transferring (selling) the rights embodied in intellectual deliverables and specific products or services, and exercising one's rights to intellectual deliverables during the monopoly manufacturing of such products (Spiridonova, 2009).

Although intellectual property management strategies and their legal protection are of primary importance for any organization, regardless of its type, legal form and objectives, most Russian universities are budgetary institutions (Poddubnaya et al., 2021) that develop their mechanism of legal protection and use intellectual property in conformity with other factors than economic efficiency and value enhancement. For example, a large manufacturing company uses patenting to enter a protected market and discourage competitors from entering the existing market.

The table below demonstrates the main elements of an intellectual property management strategy at the life cycle stages of intellectual deliverables.

Table 1. Strategies for intellectual property management.

\begin{tabular}{|c|c|c|}
\hline $\begin{array}{l}\text { The life cycle stages of intellectual } \\
\text { deliverables }\end{array}$ & The form of intellectual deliverables & $\begin{array}{l}\text { The action of an intellectual property } \\
\text { management unit at each stage }\end{array}$ \\
\hline 1. Planning intellectual deliverables & R\&D objects & $\begin{array}{l}\text { The study of industry trends and } \\
\text { technical levels }\end{array}$ \\
\hline 2. Creating intellectual deliverables & Protectable intellectual deliverables & $\begin{array}{l}\text { The study of patentability and patent } \\
\text { frequency }\end{array}$ \\
\hline 3. Obtaining legal protection & $\begin{array}{l}\text { The transformation of intellectual } \\
\text { deliverables into intellectual } \\
\text { property objects }\end{array}$ & $\begin{array}{l}\text { Selecting the form of registering } \\
\text { rights to intellectual deliverables }\end{array}$ \\
\hline $\begin{array}{l}\text { Accounting and using intellectual } \\
\text { property objects }\end{array}$ & $\begin{array}{l}\text { Intellectual property objects and } \\
\text { intangible assets }\end{array}$ & $\begin{array}{l}\text { Verification as intangible assets. } \\
\text { Registering a statement of use }\end{array}$ \\
\hline $\begin{array}{l}\text { Commercializing } \\
\text { property objects }\end{array}$ & Innovations & $\begin{array}{l}\text { The conclusion of a license } \\
\text { agreement or transfer of rights }\end{array}$ \\
\hline
\end{tabular}

The pioneers in developing intellectual property policies were universities and research institutes that had been involved in the commercialization of intellectual deliverables for a long time. They had already formed standard procedures related to the management of intellectual deliverables and used them as a basis of their intellectual property policy. One of the first Russian universities that developed and adopted a policy in the field of intellectual property was the Ural Federal University (Vasileva, 2018). Until 2010, the basis of intellectual property management at the Ural Federal University had been the legal protection of intellectual deliverables created at this university. Since 2011, its intellectual property policy has shifted towards the most effective use of 
intellectual deliverables created in the interests of the university, its employees, students, graduate students and society as a whole. The implementation of this policy requires active interaction between universities and businesses to commercialize such innovations. The leading Russian universities became national centers implementing intellectual property policies, including Bauman Moscow State Technical University, St. Petersburg National Research University of Information Technologies, Mechanics and Optics (ITMO University), Peter the Great St. Petersburg Polytechnic University, National Research University - Higher School of Economics, Tver State University, Vologda State University, Tyumen State University, etc. (Vasileva, 2018).

There are two methods used by the Russian universities in forming an intellectual property policy: 1) to develop a small document as a criterion of the university's intentions in the field of innovation. On its basis, specific local documents are adopted in the form of regulations, codes and recommendations, etc. that govern relations on the creation and use of intellectual deliverables; 2 ) to form a large document containing all the aspects of a university policy in the sphere of intellectual property. If we conduct a general analysis of the structure of intellectual property policies of various Russian universities and research institutes, we can identify its main components, namely: the issuance of a legal document, a conflict of interest, the distribution of income received from the implementation of intellectual deliverables, the motivation of scholars, etc. (Vidyakina, 2013). Each university decides on its intellectual property policy depending on the development of its intellectual property. Then such an institution develops its own procedure for managing the rights to intellectual deliverables and selects various tools to achieve this goal (Vidyakina, 2016). For instance, the rights to reproduce and distribute educational and methodological materials created during the performance of employees' labor duties belong to the Ural Federal University. On the contrary, the Higher School of Economics proceeds from the need to secure the exclusive right to intellectual deliverables for their authors. These differences are associated with various profiles and statuses of universities: the first is a partner of the Ural innovative industry and the second is the All-Russian expert on economic issues (Tarasov, 2016).

The lack of necessary resources (innovative infrastructure, personnel, etc.) is not the only difficulty. The most important one is the recognition of intellectual property as a strategic resource of universities that can increase their competitiveness not only in Russian but also in the world market of educational and scientific services. This recognition should be accompanied by appropriate managerial decisions. It is worth mentioning that the formation of an intellectual property policy is a long-term procedure and it is not needed by every university, but mainly by those involved in the commercialization of intellectual deliverables. In this regard, the Ministry of Science and Higher Education of the Russian Federation took this task under its control (Vasileva, 2018).

To support the development and adoption of intellectual property policies by the Russian universities and research institutes, there is a need for a standard comprehensive document considering various aspects of the creation of intellectual deliverables, the protection and commercialization of rights to intellectual property. Many universities could use this document as a basis. The Ministry of Science and Higher Education of the Russian Federation, the Russian Federal Service for Intellectual Property and the Russian State Academy of Intellectual Property developed the "Model Regulation on Intellectual Property Policy in Universities and Research Institutes" (WIPO n.d.). The World Intellectual Property Organization verified this document.

This is an important step in the development of intellectual property in Russian universities and research institutes. The approach will facilitate the issuance of specific documents in various universities.

Such documents will help not only in organizing internal regulations for working with the intellectual property but also in ensuring the interaction of universities or research institutes 
with federal authorities, partners and customers, and, consequently, in the commercialization of intellectual property (Ivliev, 2017, p. 2).

A typical document considers the balance of interests among institutions, authors/developers, third-party organizations, society/state. It reflects the following three aspects: 1 ) there is an answer to the question of why science and education need intellectual property; 2 ) recommendations are developed for universities and research institutes on the management of intellectual property objects and rights to them at each stage of innovation life cycles; 3 ) each recommendation is proved by the successful implementation of the corresponding measures by the Russian universities or research institutes. The adoption of a specific policy in the field of intellectual property within each university should be accompanied by the development of local acts on intellectual property management that relate to accounting intellectual property objects and intellectual deliverables, identifying technologies for their recognition and assessing the effectiveness of their use. To speed up the solution of the tasks set, the Russian Federal Service for Intellectual Property works on proposals to reduce funding for universities and research institutes that do not have a system of local acts on intellectual property management. The Russian State Academy of Intellectual Property (a department of the Russian Federal Service for Intellectual Property) has developed two advanced training programs: 1) "A university intellectual property policy" for heads of universities and research institutes (vice-rectors, heads of departments for intellectual property management and commercialization); 2) "Intellectual property management at universities: the best practices. Local regulatory acts for the implementation of intellectual property management processes" (for specialists) (Vasileva, 2018, p. 177). These programs aim at meeting the growing market demand for specialists in the sphere of intellectual property.

Each university should adopt an intellectual property policy together with uniform mechanisms for its implementation. Many technical universities face a common problem that they have experience in managing intellectual property mainly for the results of scientific research for which state registration is required or possible (inventions, utility models, computer programs, etc.) and pay insufficient attention to the distribution of rights to the objects primarily used in the educational process. Therefore, the management of intellectual property in a university should also serve the interests of the educational process and commercialize the corresponding results (Ryzhov, 2018). Consequently, a university policy should provide a unified management and organization system, expand the functions of the relevant departments, officials and collegial bodies, consider the needs of both scientific and educational activities within this university.

One of the policy objectives is to prevent and resolve conflicts arising in connection with the creation and use of intellectual deliverables. To solve this issue, it is necessary to extend the action of such a policy through concluding agreements (or including the relevant clauses in other agreements) with employees, students and persons working under civil contracts. A separate section of this policy should be concerned with mechanisms for resolving disputes and preventing conflicts of interest, i.e. situations in which the personal interest (direct or indirect) of an employee affects or might affect the proper performance of their duties, and in which a contradiction arises or might arise between the personal interest of an employee, the rights and the legitimate interests of a university leading to property damage, decrease in income or other benefits, and/or deterioration of the university's reputation (Ryzhov, 2018). Additional requirements in the development of such a policy are associated with its focus on a wide audience of employees and students who should become familiarized with the document. This stipulates the need to limit the document to only the basic principles and mechanisms of intellectual property management at universities without their detailed description and regulation. The basis for developing intellectual property policies is the current legislation (Part Four of the Civil Code of the Russian Federation; Federal Law No. 98-FZ of July 29, 2004 "On Commercial Secrets"), the "Model Regulation on 
Intellectual Property Policy in Universities and Research Institutes" developed by the World Intellectual Property Organization (n.d.), the Law of Intellectual Property by the National Research University Higher School of Economics (2013b) and the Code of Practice on Intellectual Property adopted by the National Research University Higher School of Economics (2013a). One of the key issues is the scope of such a policy, both in terms of intellectual deliverables and the categories of persons and activities to which it applies. For example, the current version of this document covers only intellectual deliverables and does not apply to means of identification, for which it is planned to develop a separate provision. The above-mentioned document reflects the specifics of technical universities. In particular, some types of intellectual deliverables are not mentioned (for example, selective breeding results) since they are not found in the university's practice. The limitation of the proposed policy to only educational and scientific activities is not fundamental but requires additional analysis of the possible consequences of its application (in terms of distributing the rights to intellectual deliverables) on other types of university activities. The document should have a traditional structure (Ryzhov, 2018). The main issue is the principles of distributing the rights to intellectual deliverables between the university and the authors. Particular attention should be paid to commercializing and stimulating the creation of intellectual deliverables, as well as distributing the corresponding income as the Russian legislation in this area differs significantly from other countries, especially in terms of the author's rights to remuneration (HEIP-link, n.d), and largely depends on a university policy. There are additional sections on information disclosure, privacy, intellectual property protection, liability and dispute resolution. Some definitions are given right in the text to make the document more understandable to a wider audience. Due to the need to limit the scope of the document, universities should develop local acts regulating the management of various types of intellectual deliverables (provisions, methodologies, etc.) (Bliznets, 2014), including provisions on patented and copyright objects, the remuneration of authors.

\section{DISCUSSION}

To ensure the effective management of intellectual property, Russia should adopt the experience of other universities in developing management policies. The US legislation makes universities use federal-funded intellectual property regardless of an economic effect. In particular, this refers to the Bayh-Dole Act of 1980 and Public Law 96-517 (Yanykina, 2011).

In 1975, Harvard University (USA) initially adopted a framework document entitled "Policy in Regard to Inventions, Patents and Copyright". It was amended once in 1986 and twice in 1998, then revised in 2008 and renamed into "Statement of Policy in Regard to Intellectual Property" (Harvard's Office of Technology Development, 2019). Further adjustments to the document were made in 2010 and 2013. This policy aims at establishing a unified approach to intellectual property management in terms of the legal protection of intellectual property objects, protecting the rights of authors and copyright holders, promoting the use of the intellectual property with due regard to the interests of all stakeholders and public interests, as well as developing mutually beneficial cooperation among the structural divisions of Harvard University and third parties (Kalinin \& Nechepurenko, 2018). The policy comprises the following categories of intellectual property objects, to which it extends its action: 1 ) inventions and patents; 2 ) copyright objects; 3 ) computer software; 4) non-patentable objects. Each group of intellectual property objects includes definitions of its objects and approaches to determining the right holder and distributing economic benefits from the use of rights to these objects. Harvard University is the right holder in case it financially supported the creation of an intellectual property object, including in the framework of various research and development programs, or provided its own property (except when this use was incidental or insignificant) (Technical University of Munich - Office for Research and Innovation Transfer, n.d.). If an intellectual property object was created as a result of the interaction (by order) with a third party, the copyright holder can be determined within the framework of these 
agreements. To regulate the distribution of income from using intellectual property objects for all the participants related to these objects, the document established the standard shares of net royalties. They are defined as the difference between the total amount of income received from the use of rights to intellectual property objects and the costs incurred by Harvard University for the creation and implementation of protection documents for industrial property objects, including legal costs, licensing costs and the costs of manufacturing and delivering non-patentable objects. In relation to the income received from the use of rights to intellectual property objects, the following procedure for determining standard shares was established on October 4, 2011. Initially, an administrative fee of $15 \%$ is charged. The rest of net profits is distributed as follows: 1 ) the personal share of the authors $-35 \% ; 2$ ) the share of the laboratory (structural unit) where the object was created $-15 \%$; 3 ) the share of the Department/Institute which includes the structural unit $-15 \%$; 4) the share of the School (College/Institute) included in the structure of the university, to which the structural unit of the author belongs $-20 \%$; 5) the share of the President of the University 15\%. If intellectual property objects are commercialized by the Technology Acceleration Fund, which brings together all the R\&D programs and projects funded by Harvard University, new standard shares of distributing net royalties are applicable starting from October 4, 2011. After an administrative fee in the amount of $15 \%$ is charged, the remaining part is distributed as follows: 1 ) the personal share of authors $-35 \%$; 2 ) the share of the laboratory (structural unit) $-15 \% ; 3$ ) the share of the Department/Institute -10\%; 4) the share of the School (College/Institute) - 10\%; 5) the share of the President of the University - 15\%; 6) deductions to the Technology Acceleration Fund - 20\% (Kalinin \& Nechepurenko, 2018). Authors are guaranteed payments regardless of their employment at Harvard University. If an author is transferred to another structural unit, the resulting net royalties are redistributed in favor of a new place of work. At Harvard University, such a policy is implemented by the Harvard Office of Technology Development and Committee on Intellectual Property. The competence of the Harvard Office of Technology Development includes determining the most promising ways of introducing intellectual property objects into civil relations, promoting their commercialization, keeping records of such objects, ensuring the patenting and securing of rights to intellectual property objects, distributing income from the use of rights to such objects. To perform these functions, the office establishes the procedure for conducting certain actions and sets rules for their document support. The functions of this office also include administering the activities of the Technology Acceleration Fund. The Committee on Intellectual Property ensures strategic decisions on intellectual property by making amendments and additions to the existing policy. The committee is also responsible for clarifying specific policies and resolving conflicts. The intellectual property policy of the University of Munich (Germany) was adopted in accordance with the European Commission Recommendation of April 10, 2018. The policy should ensure the university's activities aimed at the development of entrepreneurship. This policy is implemented on the basis of the following principles (Technical University of Munich - Office for Research and Innovation Transfer, n.d.): new ideas, products and technologies should aim at obtaining the most positive social effect; despite the importance of public interest, the university shall ensure the commercial effectiveness of these ideas, products and technologies, including for the purposes of material incentives for the authors of intellectual property objects while recognizing the significance of their work; decisions on the further use of intellectual property objects are made with due regard to the opinion of their authors; the university protects the rights of such authors but the latter retain the right to publish the results achieved in the framework of their research; intellectual deliverables can be used in the formation of start-up and spin-off companies and the university has the right to participate in the implementation of these projects and provide possible assistance; the commercialization of intellectual property objects should consider the personal nonproperty rights of their authors and indicate the connection of the results obtained within the University of Munich. The policy identifies the following categories of intellectual property objects, 
to which it applies: 1) inventions and patents for other industrial property objects; 2) nonpatentable objects; 3 ) computer software (Technical University of Munich - Office for Research and Innovation Transfer, n.d.). The University of Munich is the copyright holder of the intellectual property objects created in the course of official duties and/or when using the university's property. When creating an intellectual property object that does not fall under the category of employmentrelated, its authors should notify the university about the creation of this object to prevent a possible conflict of interest. When distributing economic benefits from the use of rights to intellectual property objects, approaches are determined by the category of the object used. Upon the commercialization of patents, the copyright share is $30 \%$, and the remaining remuneration is evenly divided between the university administration and the Department/Institute where the object was created (Technical University of Munich - Office for Research and Innovation Transfer, n.d.). When using other objects, the share of authors is determined in each case individually, but the rest should be divided equally between the administration of the university and the Department/Institute. The authors from Harvard University are guaranteed payments regardless of their current employment at the University of Munich. If such an author changes a structural unit, the resulting net royalties might be redistributed in favor of a new place of work. The functions of accounting new objects, determining and ensuring the most promising forms of legal protection, promoting the further use of intellectual property objects are assigned to the department of patenting and licensing (Technical University of Munich - Office for Research and Innovation Transfer, n.d.).

The table below compares the principles and structures of intellectual property management policies developed by various universities.

Table 2. Comparing the principles and structures of management policies.

The university that adopted and implemented a policy on the creation, use and
protection of intellectual property

The purpose of policies

Principles for policy implementation and intellectual property management

The identification of copyright holders

Students' rights to intellectual property

The distribution of income from the use of intellectual property

Confidentiality procedure

Dispute resolution

Organizational structure for policy implementation

Subdivisions contributing to the commercialization of intellectual property

The use of intellectual property in the creation of spin-off and start-up companies 
The commercialization of intellectual deliverables

Responsibility

Based on the study conducted, we have revealed the following key components of the policy of universities in the field of intellectual property. Firstly, their intellectual property policies have a clear objective. Classical universities strive to establish a unified approach to intellectual property management in terms of the legal protection of intellectual property objects, to protect the rights of authors and right holders, to promote the use of the intellectual property with due regard to the interests of all the parties involved and the overall public interest. Technical universities prefer developing entrepreneurship. Secondly, all the policies contain principles for their implementation and intellectual property management. Thirdly, special attention is paid to the identification of the right holders to intellectual property objects, including the intellectual property created by students. As a rule, the rights to employment-related intellectual property objects are assigned to the university based on a local regulatory act or by concluding an agreement with an employee (student) who is the author of the above-mentioned intellectual property object. In several cases, such rights can be transferred to employees and students. Fourthly, all the policies clearly outline approaches to material incentives for authors, structural divisions of universities and schools, colleges, etc. for the creation and use of intellectual property objects. All the universities have specific shares of the resulting net profit for authors, administrative structures and other participants in the commercialization of intellectual property objects. The priority direction of material incentives for the authors of intellectual property objects is the definition of approaches and guarantees of their rights and interests in the distribution of the received economic benefits from the use of the corresponding intellectual property objects. Fifthly, all the universities have an organizational structure for intellectual property management that ensures decision-making on various issues related to the creation, legal protection and use of intellectual property objects and, if necessary, the protection of rights to these objects. In addition, the policy can be supplemented by various documents developed on its basis that regulate the procedure for patenting, selecting the form of legal protection, stimulating the authors of intellectual property objects, the functioning algorithm of the structure responsible for the commercialization of intellectual property, etc. The content of intellectual property policies for each university is mostly determined by the state's innovation policy, its national legislation, the main goals and objectives of a particular university, as well as real opportunities for implementing an intellectual property policy.

In general, the use of international experience in the activities of the Russian universities can have a positive impact on their involvement in innovative processes, including within the framework of international scientific and technical cooperation. A competent approach will help to implement the achievements of university science in the real sector of the economy. However, the imitation of the policies, procedures and rules of universities from other countries (for example, the United States) does not have any tangible results. The reason is the specifics of intellectual activity in various universities and different levels of its development in the compared countries. Furthermore, special units responsible for intellectual property management in the US universities proceed from the principles of accessibility and usefulness of new knowledge and new technologies for society in their activities. In Russia, an emphasis is laid on maintaining the competitiveness of universities in the educational services market.

\section{CONCLUSION}

A specific policy for managing the intellectual property of a university considers its features as information, a resource and a product, as well as the factors that affect the goal-setting of the university. 
It seems expedient to represent such a policy in the form of a regulatory complex, where the main local act is supplemented with additional university acts. Corresponding to the existing legislation of a higher level, the main act sets the goals and principles of managing intellectual property objects, as well as the rights, duties and responsibilities of all participants in such legal relations. Thus, the research hypothesis seems to be proven.

Considering a growing trend to corporatize universities and transform them into entrepreneurial institutions, whose priority is to increase income, ensure self-financing and selfdevelopment, it is necessary to introduce elements of control over economic efficiency into intellectual property management policies. In addition, it is required to consider the orientation of universities towards the production of knowledge for the benefit of society.

One more direction of a university intellectual property management policy is the preservation and development of its scientific and technical potential as a strategic resource and a factor of competitiveness. Forming a system capable of maintaining the balance of these strategies should be considered a priority task of such a policy.

Authors' Contributions: Alexander Evgenievich Suglobov: designed the study, prepared the plan, wrote the first draft of the manuscipt and edited the final version. Katerina Sergeevna Orlova: designed the study, prepared the plan, wrote the first draft of the manuscipt and edited the final version. Alexander Konstantinovich Kalliopin: designed the study, prepared the plan, wrote the first draft of the manuscipt and edited the final version. Petr Katys: designed the study, prepared the plan, wrote the first draft of the manuscipt and edited the final version. Aleksey Valeryevich Novikov: designed the study, prepared the plan, wrote the first draft of the manuscipt and edited the final version. All authors have read and approved the final version of the manuscript.

Ethics Approval: Not applicable.

Acknowledgments: Not applicable.

\section{REFERENCES}

Abdulkadyrov, U. U., Pak, O. A., \& Makushkin, S. A. (2021). Regulation of professional and labor relations of university teachers: international practice and national characteristics. Revista Tempos E Espaços Em Educação, 14(33), e15129. https://doi.org/10.20952/revtee.v14i33.15129

Bliznets, I. A (2014). Politika universitetov v sfere intellektualnoi sobstvennosti [Intellectual property policies implemented by universities]. Mezhdunarodnyi pravovoi kurer, 3, 11-15.

Bostock, W. W. (1999). The global corporatization of universities: causes and consequences. AntePodium, III. Available: https://eprints.utas.edu.au/8390/

Ermilov, V. G., Azhmuratova, M. A., Pogrebinskaya, E. A., \& Novikov, A. V. (2020). Desarrollo climático de inversiones: mecanismo normativo legal dentro del marco de desarrollo de la unión económica Eurasiana. REICE: Revista Electrónica De Investigación En Ciencias Económicas, 8(16), 150-165. https://doi.org/10.5377/reice.v8i16.10678

Glinkina, O. V., Ganina, S. A., Soloveva, M. V., Litvinov, A. N., Smirnova, I. L. (2020). Current trends and directions of development of the international economic environment. IIOAB Journal, 11(S3), 8-12.

Harvard's Office of Technology Development. (2019). Statement of Policy in Regard to Intellectual Property (IP Policy). Available: https://otd.harvard.edu/faculty-inventors/resources/policies-and-procedures/statement-of-policy-inregard-to-intellectual-property/\#top

HEIP-link. (n.d.). Promoting the international dimension of research in HEls. Available: http://www.heip-link.net

Ivanov, V. A., Andrianov, Yu. S. Vasyunina, E. Z., Sharapov, E. S., \& Nekhoroshkov, P. A. (2012). Intellektualnaya sobstvennost universiteta: sozdanie, pravovaya okhrana i upravlenie [The intellectual property of universities: formation, legal protection and management]: scientific edition. Yoshkar-Ola: Povolzhskii gosudarstvennyi tekhnologicheskii universitet, $352 \mathrm{p}$.

Ivliev, G. P. (2017). Doklad rukovoditelya Rospatenta na konferentsii "Modeli sistem upravleniya intellektualnoi sobstvennostyu v rossiiskikh universitetakh i nauchnykh organizatsiyakh" [The report of the head of the Russian Federal Service for Intellectual Property at the conference "Models of managing intellectual property in the Russian universities and research institutes]. Moscow, Skolkovo. 
Kalinin, A. Yu., \& Nechepurenko, Yu. V. (2018). Politika universiteta v oblasti intellektualnoi sobstvennosti: zarubezhnyi opyt [A university policy in the sphere of intellectual property: foreign experience]. Intellektualnaya sobstvennost $v$ Belarusi, 3(79), 16-22.

Kalinin, A. Yu., \& Nechepurenko, Yu. V. (2019). Politika v oblasti intellektualnoi sobstvennosti: opyt universitetov Irlandii [Intellectual property policy: the experience of Irish universities]. Aktualnye problemy nauki XXI veka, 8, 37-42.

Klimakina, E. A., Palanchuk, N. V., Golovyashkina, M. A., Kagosyan, A. S., \& Popova, O. V. (2020). Desenvolvimento da aprendizagem hibrida nas universidades: características organizacionais e legais. Laplage Em Revista, 6(Extra-C), 215222. https://doi.org/10.24115/S2446-622020206Extra-C644p.215-222

Liotard, I. (1999). Les droits de propriete intellectuelle, une nouvelle arme strategiqie des firmes. Rev. d'ecomonie industrielle, 89, 69-106.

National Research University Higher School of Economics. (2013a). Kodeks praktiki v oblasti intellektualnoi sobstvennosti Vysshei shkoly ekonomiki [The Code of Practice on Intellectual Property adopted by the National Research University Higher School of Economics]. Available:

https://www.hse.ru/data/2014/01/22/1325729520/\%D0\%9A\%D0\%BE\%D0\%B4\%D0\%B5\%D0\%BA\%D1\%81\%20\%D0\%B F\%D1\%80\%D0\%B0\%D0\%BA\%D1\%82\%D0\%B8\%D0\%BA\%D0\%B8\%20\%D0\%B2\%20\%D0\%BE\%D0\%B1\%D0\%BB.\%20\%D0 \%98\%D0\%A1.pdf

National Research University Higher School of Economics. (2013b). Polozhenie ob intellektualnoi sobstvennosti NIU VShE [Law of Intellectual Property by the National Research University Higher School of Economics]. Available: https://www.hse.ru/docs/109614047.html

Poddubnaya, T. N., Zadneprovskaya, E. L. Voevodina, S. S., Ilyinova, N. A., Khatit, F. R., \& Panina, E. A. (2021). Distance learning experience in the context of globalization of education]. Propositos y Representaciones, 9(1), e985. Available: http://revistas.usil.edu.pe/index.php/pyr/article/view/985 (date of access: February 3, 2021).

Ryzhov, N. G. (2018). Politika tekhnicheskogo universiteta v oblasti intellektualnoi sobstvennosti [Intellectual property policies of technical universities]. Innovatsii, 10(240), 7-13.

Shegelman, I. R. (2010). Universitet v innovatsionnom prostranstve regiona [Universities in the innovative environment of a region]. Vysshee obrazovanie $v$ Rossii, 8-9, 77-80.

Spiridonova, E. A. (2009). Ekonomicheskoe obosnovanie strategii kommertsializatsii intellektualnoi sob stvennosti [The economic justification of a strategy for intellectual property commercialization]. Thesis for a Candidate Degree in Economic Sciences. Saint Petersburg State University, Saint Petersburg.

Tarasov, O. A. (2016). Originalnaya politika v oblasti intellektuanoi sobstvennosti, kak kriterii namerenii vuza v sfere innovatsii [A specific policy in the sphere of intellectual property as a criterion of an innovative potential of some university]. Zhurnal "Innovatsii. Investitsii", 7(89), 3.

Technical University of Munich - Office for Research and Innovation Transfer. (n.d.). TUM IP Policy. Available: https://www.forte.tum.de/en/technology-transfer/patents-and-licenses/tum-ip-policy/

Vasileva, Yu. S. (2018). Polozhenie del v Rossiiskoi Federatsii v otnoshenii politiki v oblasti intellektualnoi sobstvennosti universitetov i nauchnykh uchrezhdenii [The state of affairs in the Russian Federation in relation to intellectual property policies implemented by universities and research institutes]. In: Gulyayev, G.Yu. (Ed.). Ekonomika, biznes, innovatsii. Proceedings of the $4^{\text {th }}$ International scientific conference, Penza, Russia. Penza: Nauka i Prosveshcheniye, pp. 176-180.

Vidyakina, O. V. (2013). Ispolzovanie zarubezhnogo opyta dlya formirovaniya politiki v sfere intellektualnoi sobstvennosti rossiiskikh universitetov [The use of foreign experience for forming a policy in relation to the intellectual property of the Russian universities]. Imushchestvennye otnosheniya $v$ RF, 3(138), 73-82.

Vidyakina, O. V. (2016). Genezis v sfere intellektualnoi sobstvennosti universitetskoi sistemy Rossii [The genesis of intellectual property in the Russian system of higher education]. Zhurnal Intellektualnaya sobstvennost. Promyshlennaya sobstvennost, 3, 45-56.

Vinokurov, V. I. (2005). Osnovnye terminy i opredeleniya v sfere innovatsii [Basic terms and definitions in the sphere of innovations]. Innovatsii, 4(81), 6-22.

Volkova, T. I. (2001). Intellektualnaya sobstvennost v nauke i tekhnike [Intellectual property in science and technology]. Intellektualnaya sobstvennost: pravovoe obespechenie: Analiticheskii Vestnik, 37. Available: http://iam.duma.gov.ru/node/8/4483/14955 
World Intellectual Property Organization (WIPO). (n.d.). Tipovoe polozhenie o politike v oblasti intellektualnoi sobstvennosti dlya universitetov i nauchno-issledovatelskikh uchrezhdenii [Model Regulation on Intellectual Property Policy in Universities and Research Institutes]. Available: http://www.wipo.int/export/sites/www/dcea/en/pdf/Tool Cover Model Policy rus .pdf

Yanykina, N. O. (2011). Strategicheskoe upravlenie intellektualnoi sobstvennostyu: spetsifika nauchnoobrazovatelnogo kompleksa [The strategic management of intellectual property: the specific scientific and educational complex]. Universitetskoe upravlenie: praktika i analiz, 3(73), 37-44.

Zamiralova, T. A., Sizikova, V. V., Karpunina, A. V., Shimanovskaya, Ya. V., \& Kvitkovskaya, A. A. (2020). Influence of university advertising activities on competitiveness in the educational services market. IIOAB Journal, 11(S3), 49-51.

Received: 31 May 2021 | Accepted: 15 July 2021 | Published: 30 July 2021

This is an Open Access article distributed under the terms of the Creative Commons Attribution License, which permits unrestricted use, distribution, and reproduction in any medium, provided the original work is properly cited. 